\title{
Notes on Terms and Concepts
}

\author{
Kosovo, Serbia Proper \\ and (Former) Yugoslavia
}

The geographic focus of this book is Kosovo. Until 1990, Kosovo was known as an "autonomous province" of Serbia, one of six Yugoslav republics. (The other autonomous province was Vojvodina.) From 1968 to the mid-I980s, Kosovo became increasingly more autonomous from Serbia. The history of the relationship between Serbia and Kosovo, as traced in the various Yugoslav constitutions, can be found in the chronology at the back of this book.

In 1989-1990, Kosovo was stripped of its autonomous status and became just a province of Serbia. All but two of the republics of what had been Yugoslavia became their own states - the countries of Slovenia, Croatia, Bosnia-Herzegovina and Macedonia. The remaining two republics, Serbia and Montenegro, called themselves Yugoslavia, and after the war ended in Bosnia-Herzegovina in 1995, most (but not all) members of the international community recognized this Yugoslavia. Kosovo has never been recognized as an independent country by any state other than Albania.

After years of simmering tensions in Kosovo, marked by human rights abuses perpetrated by Serbs against Kosovo Albanians, armed conflict erupted in Kosovo in I998. The main arguments about the status of Kosovo are mirror opposites of one another. According to the dom- 
inant Serbian position, Kosovo is an inalienable component of Serbia in Yugoslavia. In making their argument, Serbs rely heavily on historical claims to land. Kosovo, they say, is so important to Serbian national identity that it is like a Serbian Jerusalem. They supplement these contentions with contemporary stories about human rights violations perpetrated by Kosovo Albanians against Kosovo Serbs, with the stories discussed in this book holding a central position in such discourse. When referring to Kosovo, Serbian officials use the name Kosovo and Metohija (or Kosovo-Metohija, or Kosmet for short).

According to the majority of Albanians living in Kosovo, the status of Kosovo came into question when Serbian politicians stripped it of its autonomy using impermissible and even illegal means. The break-up of Yugoslavia, they contend, threw open all questions of sovereignty within Yugoslavia, and Albanians living in Kosovo have voted for autonomy and established their own government. Kosovo Albanians make theirown historical arguments regarding the longevity of their people in the region and for the centrality of Kosovo for Albanian national identity. They further underscore that years of gross Serbian human rights abuses against Albanians have made a continued union untenable. When referring to Kosovo, Albanians would use the Albanian-language name Kosova or Kosovë.

When using the term Kosovo, this book refers to the geographic area that has long been known as Kosovo. Use of this term, however, does not indicate a position on the larger issue of the political status of Kosovo today or in the future. When referring to Serbia without Kosovo and Vojvodina - "the rest of Serbia," if one considers those two formerly autonomous provinces to be part of Serbia - the book uses the term Serbia proper.

The term Yugoslavia when used in reference to the period before the most recent wars, refers to the internationally recognized state of the time, with its six constituent republics and, up until 1989, two autonomous provinces. When referring to the period after most of the republics became new states, Yugoslavia refers to Serbia proper, Kosovo and Montenegro.

Serbs, Albanians, Kosovo Albanians and Kosovars

This book is primarily about the building of national identity among Serbs living anywhere in Yugoslavia and Albanians liv- 
ing in Kosovo. The complication here is that Albanians of course also live in Albania (and in large numbers in Macedonia). In fact, Albanians are one of the most numerous diasporas in the world.

In this book the term Kosovo Albanians (or Kosovar Albanians) refers to Albanians in or from Kosovo, thus distinguishing them from Albanians from Albania, Macedonia and elsewhere. Kosovo Serb is used to specify Serbs living in Kosovo. The general terms Kosovor or Kosovar refer to anyone from Kosovo, including not only Albanians and Serbs but also Montenegrins, Croats, Muslims and Turks.

\section{Language}

One major dilemma in writing about Kosovo concerns whether to use Albanian or Serbian (until the break-up of Yugoslavia, "Serbo-Croatian") names of places. Sometimes the differences can seem minor, such as Kosovo (Serbian) versus Kosova (Albanian), and sometimes they can be enormous, such as Uroscevac (Serbian) versus Ferizej (Albanian). Throughout the 1970 s and early 1980s, the Albanian language was used widely in Kosovo in official business. From the late I980s onward, official business was conducted in Serbian. Serbs and Albanians together spoke Serbian, but among themselves Albanians spoke Albanian. Today, Serbs would rather speak their first language, Serbian, and Kosovo Albanians would rather speak the language they learn at home, Albanian. The majority of world atlases have always used spellings similar to those of the Serbian language. This book takes the easy way out by reverting to the atlases. Serbian is used for place names throughout, although this choice in no way signals a position on the language policy in Kosovo.

\section{Nation, Ethnic Group, Ethno-National Minority}

In this book, nation does not refer to a state. Rather, nations are groups united by real and imagined markers such as history, language and traditions. ${ }^{1}$ Shared myths and memories hold key importance in the definition of nations. In Will Kymlicka's terms, "'nation' 
means a historical community, more or less institutionally complete, occupying a given territory or homeland, sharing a distinct language and culture." Leaders of nations attempt to advance purported common interests through organized political action; although they do not always desire their own state, nations often seek some kind of cultural and/or political autonomy.

Both Serbs and Albanians consider themselves to have these markers and to be nations, so this book uses the term to apply to both groups. This is contrary, however, to official usage in the former Yugoslavia. Under the 1974 Constitution of Yugoslavia, the nations (narodi) were Serbs, Croats, Slovenes, Macedonians, Montenegrins and Muslims. (Muslims were the last group to be added to this list.) Those with a "national homeland" in another state, such as Albanians and Hungarians, were considered to be "national minorities" (manjina or narodnosti); those without a homeland anywhere, such as the Rom, were labeled "ethnic groups." The chronology at the back of this book traces the development of these concepts in Yugoslavia.

The term ethnic group is also applied to both Serbs and Albanians, because they consider themselves to be ethnically distinct from each other. That is, they believe that they constitute a primary cultural unity and share common cultural interests. Ethnic groups exhibit, in varying degrees, the following factors: real or imagined common ancestry, shared historical memories, a link with a homeland, and one or more elements of a common culture, such as religion, customs and language. ${ }^{3}$ Ethnic groups may be distinguished from nations in that ethnic groups need not seek to advance their interest through organized political action. When members of an ethnic group "interact regularly and have common interests and organizations at a collective level"4 they are said to be ethnic communities. In this sense, ethnic communities may be equated with nations. References in this book to ethnic Albanians or etbnic Serbs are generally to people who are part of ethnic communities.

At times, the term ethno-national is used to collapse ethnicity and nation into a (slightly improper) nomenclature. Ethno-national minorities is something of a compromise between the more European use of "nation" and the American use of the term "ethnic groups." The wording "ethno-national" is useful as it underscores that members of the group in question locate solidarity at a collective level and that collective action may emerge from shared understandings of a unique past. 


\section{Sources and Methodology}

The backbone of this work is a series of interviews conducted in Kosovo and Serbia proper in 1993-1995 and supplemented by subsequent interviews in Macedonia in 1996 and Kosovo in 1998. Apart from background interviews, which were conducted widely, the author focused on Albanians and Serbs who were students in 1981. When not specified, the author conducted all interviews. In some cases, the interviewee was hesitant to speak candidly with a foreigner, and interviews by local people solicited more open responses. Whenever the author did not conduct interviews, the interview was conducted by a Kosovo Serbian or Albanian independent researcher of the same age as the author. In all cases, factual statements were corroborated. References to secondary sources were included in order to provide a guide to further scholarship. Nearly all of these sources can be found in the Harvard University library. Hard-to-find Serbian language books were acquired largely through used book vendors in Belgrade.

The layered use of interview, text and interpretation provides a microexamination of the development of national identity in Kosovo. While a macro-examination of the history of Kosovo is valuable as well, ${ }^{5}$ a micro-analysis is needed if we are to understand how the telling of myths and truths started a war. Although tensions between Serbs and Albanians have long existed, the war in Kosovo was not preordained by ancient hatreds. Rather, the war was ignited by more recent storytelling. The goal of the methodology employed in this book is to shed light on the process of identity formation and to underscore the connection between a victimhood identity and the potential for conflict.

\section{Notes}

I. See, e.g., Benedict Anderson, Imagined Communities: Reflections on the Origins and Spread of Nationalism (London: Verso Books, 199I).

2. Will Kymlicka, Multicultural Citizenship (Oxford: Oxford University Press, 1995).

3. See generally Anthony D. Smith, The Ethnic Origins of Nations (Oxford: Blackwell, 1996); Donald Horowitz, Ethnic Groups in Conflict (Berkeley: University of California Press, 1985); Marcus Banks, Ethnicity: Anthropological Con- 
structions (London: Routledge, 1996); Nathan Glazer and Daniel P. Moynihan, Ethnicity: Theory and Experience (Cambridge, Mass.: Harvard University Press, I975).

4. John Hutchinson and Anthony D. Smith in introduction to Ethnicity, ed. Hutchinson and Smith (New York: Oxford University Press, 1996), 6.

5. After this manuscript was completed, Noel Malcom and Miranda Vickers made significant contributions to our macro-understanding of the history of Kosovo. See Noel Malcolm, Kosovo: A Short History (New York: New York University Press, 1998), and Miranda Vickers, Between Serb and Albanian: A History of Kosovo (New York: Columbia University Press, 1998). 